\title{
An essay on tourism and natural resources: a cause of political conflicts'
}

DOI: $10.22403 /$ UQROMX/TYP10/05

\author{
Yoram Krozer \\ CSTM-University Twente \\ Sustainable Innovations Academy
}

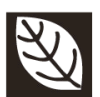

Abstract

This essay, using economic theory on monopoly exploitation of natural resources, discusses international tourism as a cause of global conflicts. The prevailing tourism pattern is the use of the (sub-) tropical seaside climate as a natural resource. This use involves multi-billion euro investments in resort development on small areas. Political conflicts emerge because recovery of the investment costs during decreasing real prices in tourism invokes monopolies in exploitation of this climate resource.Struggles for a share in the monopoly profits expand. Break-through innovations in tourism development can prevent severe tensions. These can be diversification of services, virtualization of amenities, and high-value services.

\begin{tabular}{l|l} 
KeYworDs & $\begin{array}{l}\text { Sustainability, political economy, natural resources, resorts, } \\
\text { mass tourism }\end{array}$
\end{tabular}

Recibido el 2 de febrero de 2010

Aprobado el 18 de mayo de 2010

Correo electrónico: krozer@xs4all.nl

' The essay is based on a presentation at the Conference on Peace through Tourism, Stenden University, October 22-25, 2008, in Leeuwarden, Netherlands. I am grateful to Peter Tarlow and Maia Lordkipanidze for comments. 


\section{Introduction}

Does international tourism generate crime and warfare? An answer about the hostilities forthcoming from tourism development is not found in a research data search, though it is no secret that many destinations are major loci of struggles. The reason that little attention is given to the dark side of tourism, I guess following Moscardo (2008), is that tourists seek relaxation during leisure time. Unethical behavior at destinations is considered deviant and scholars focus on continuity in tourism development, often neglecting the impacts. This view on international tourism is possibly biased and this paper discusses the threat that tourism is a major cause of political and economic conflicts.

The tourism businesses and tourists often perceive themselves as peacemakers. The self-perception of a peacemaking force has been popularized in the past decades due to the trailblazing works of Louis D'Amore (I988) and his International Institute for Peace through Tourism (IIPT), which has attracted adepts exposed in the recent volume edited by Moufakkir and Kelly (2010). Along this line of thought, the cooperation between policymakers and tourism businesses on the re-generation of conflict areas is advocated (Goldstone, 200I). It is also suggested that international tourism could contribute to conflict resolutions because it would foster a better understanding of peoples' interests (Satani, 2004; Cho, 2007; Kim, Prideaux and Prideaux, 2007). There is all reason to expect that tourists can mediate in some cases but they also cause cultural tensions. A golden bullet is still to be found.

When disasters occur, the international tourism industry considers itself a victim. The impact of natural disasters and political conflicts was much studied after the publication of the seminal volume edited by Pizam and Mansfield (1996). Plenty of studies underline the suffering of tourism after a major catastrophe or during a war, which can hardly be a surprise because only thrill seekers can remain at ease during such events. However, it is more remarkable how fast international tourism recovers (Beirman, 2006; Tarlow, 2006). International tourism often grows despite political conflicts. Moreover, the fastest growth of revenues from international tourism is found in regions with endemic political conflicts, such as the Middle East where the average growth between 1980 and 2005 was I $3 \%$, compared to $9 \%$ worldwide.A similar situation can be found in many African countries that experience domestic struggles and crime (WTO, 2006). This implies that international tourism adapts inflexibly. 
International tourism is a vivid business. The number of international journeys has increased on average by almost $5 \%$ a year between 1980 and 2005 , such that there are now in excess of 800 million tourism trips a year worldwide, and more than 550 billion euro of business income was generated in 2005, making it one of the largest international trades. Locally, it is the main income source in many small economies, such as the Mediterranean, Caribbean and Pacific islands, and it provides a large share of the national income in many large economies, such as 6\% in Thailand, $12 \%$ in Spain, and $15 \%$ in Turkey. Further, international tourism has a high growth potential because people live longer and, in parallel, they work a smaller percentage of their lifetimes. This creates more leisure time, which can be spent visiting international tourism destinations. It is particularly attractive to spend leisure time at locations where the cost-ofliving is cheaper than at one's home because some costs from at home can be avoided. International tourism would be an attractive, market-based, route to global income distribution if peaceful tourist destinations could be sustained.

This paper addresses the threat of political conflicts generated at tourism destinations using the economic theory on the monopoly exploitation of natural resources and it is argued that sustainable innovations can mitigate this. The paper starts with the economic theory on natural monopoly and discusses exploitation of two pivotal natural resources: water and fuel. Then, the main natural resource in international tourism is defined, which is a subtropical and tropical seaside climate and evolution in international tourism is addressed, which leads to the monopoly exploitation of this resource and ultimately political conflicts. Finally, we discuss a few innovative options to mitigate this threat and draw a conclusion for sustainable tourism.

\section{Despotic water and hydrocarbon societies}

The desire to control natural resources such as land, minerals, water, and fuel has been a major cause of political conflicts throughout the centuries. In the classic, liberal, economic view, the state was the legitimate controller of natural resources in its domain, but the state rulers often entitled private firms to exploit these resources in a monopolistic manner. In this way, the selected firms were privileged to sell goods at prices far above what competition would have delivered and so generated exceptionally high profits. The state 
An essay on tourism and natural resources: a cause of political conflicts

also protected monopolies against newcomers seeking a share in these monopolistic profits. With this protection, monopolies were able to survive for centuries despite repeated struggles against their concessions, protectionism, and price agreements. From the liberal economic viewpoint, the monopolies were undesirable and the state interventions to remove the entitlements for the monopoly exploitation of resources were legitimate (Smith, 1986: 163-164 [1776]; Mill, 1985: 294-296 [1848]).

The neoclassical economists modified this view in the last fifty years with the argument that monopolies can also evolve through spontaneous mergers between competing firms without state interventions. Such mergers would emerge when large investments were needed while the real prices of products were decreasing because large- scale production would become necessary to make a profit. Businesses, therefore, would evolve into a so-called 'natural monopoly'. In particular, the exploitation of natural resources would be prone to such 'natural monopolies' because the harvesting and distribution of resources from the exploitation area to users would need huge investments, while the real prices of natural resources have a tendency to decrease, which is found throughout recent centuries (Mill, 1985:64; Rosenberg, 1975:229-248; Dasgupta and Heal, 1979:439-470).

The argument against such a 'natural monopoly' being sustained is that innovators, driven by competition, create alternatives. It is, therefore, argued that the private monopoly is not imposed by the market but rather by rulers: to impede competition, to restrict the entry of innovative newcomers, and ultimately to undermine political freedom (DiLorenzo, 1996). Indeed, despotism emerges whenever pivotal natural resources, essential for subsistence, such as land, water, and fuel are at stake. The use of natural resources for tourism is no exception. For example, the success of the British tourism agency Thomas Cook in Egypt in 1870s was largely due to relation with the Egyptian dynasty that entitled the agency to monopolitic exploitation of travels on the Nile for ten years, which enabled them to generate huge profits (Scranton and Davidson, 2007).

Water is still rigidly governed because it is key resource to successful agriculture, transport and so on. Andrej Platonov, the 'workers writer' of the Soviet regime in the 1920 s, once remarked that waterworks generate despotism because they need a huge workforce. The construction of canals in the early 
stages of the Soviet regime involved millions of forced workers, many of whom died of hunger and cold, and this regime was by no means unique. Karl A. Wittfogel in his book Oriental Despotism (1957) argues that the control of water reserves involves huge infrastructures and administrations. In the "hydraulic societies", as Wittfogel calls them, the despotic rulers generated wealth for themselves through forced labor.The water facilities have gradually lost this key role because innovation has led to shifts from agriculture to manufacturing and has made water inexpensive. Mineral oil and gas then became pivotal natural resources. The "hydraulic societies" evolved into "hydrocarbon societies". In these hydrocarbon societies, oil and gas reserves on small areas of land are also usually controlled by despots that allow firms to exploit the resources and distribute them through sea corridors and pipelines. Desire for control has been a major cause of wars throughout the twentieth century. Struggles about concessions and distribution have intensified in places like Mexico and Azerbaijan in the early decades of the last century, to Algeria, Egypt, and Persia in the 1950s, and recent wars in Chechnya, Darfur, Iraq, Nigeria, and others. Innovations in renewable energy have reduced hydrocarbon dependency, which can reduce the threat of social conflicts, but progress is slow (Friedman, 2008).

In the past fifty years, innovations in communications and transport have enabled a growth of services that nowadays account for two-thirds of global income. Leisure services have boomed alongside the finance industry, and international tourism has evolved into a large leisure business. International tourism embraces many services but the key one is based on conveying tourists from all over the world to small areas of land in the Mediterranean and tropical climate zones and nurturing them with sea, sun, and sand for a week or a fortnight. This "sea, sun and sand" tourism covers about a third of all international journeys and this number grows each year. This tourism is concentrated in resorts on tiny areas of land.The resorts are often developed on small spots of bare land, since this is cheaper than situating the development in establish settlements, and these spots are transformed within a few decades into busy tourism resorts that host a few million visitors a year. For example, Cancun (Mexico) was not a tourist destination before the 1970s but now has more than I 50 hotels, as well as hundreds of restaurants and shops, catering for more than 4 million visitors a year.The resort was hardly planned; it simply grew through the entry of businesses that exploited the local environment. Grazyna 
An essay on tourism and natural resources: a cause of political conflicts

Przybyl (2000) describes such a development in a parable.A local community lived in a forest.A few started a forest resort. They arranged benches and paved paths for easier walking. Some tourists climbed trees and so lifts were erected to prevent accidents. Kids were taught about bird watching but mechanical birds were used because they did not fly away.An international conference center was established and people flew in from all over the world to experience all these achievements. A busy site developed and the forest disappeared.

\section{Warm air amenity}

Virtually all international tourism resorts are busy spots located on the coast. What drives hundreds of millions of people from temperate climate zones, and increasingly from the subtropical and tropical areas to travel thousands of miles and pay a lot of money every year for a stay at the tropical or subtropical seaside spot? Clearly, the climate at the warm seaside must offer an amenity that is not to be found in the temperate zones and tropical and subtropical inland, since it is usually cheaper to stay inland and close to home. The tourism promotion literature suggests that the main amenities are blue seas, fascinating culture, and unspoiled nature, but in reality the sea is usually crowded, cultural heritage may be miles away, and the nature at the resort is often artificially constructed.The amenities that attract such a massive flow of people are the warm conditions and the cool sea breezes of the tropical and subtropical seaside. The (sub-) tropical coast's warm air is the natural resource of international tourism. Such a climate is difficult to find naturally inland or to achieve with heating in health resorts.

Suitable climatic conditions for international tourism have been investigated since the early 1980s. The groundbreaking work of Mieczkowski (1985) statistically linked several climate characteristics such as solar radiation, wind, and humidity with tourist numbers. This work has resulted in the Tourism Climate Index that is widely used to assess opportunities for tourism development. The work of De Freitas ( 1985 ) on interactions between climate and the human body inspired many investigations into humidity and the body's evaporation balance, solar radiation and human heat acceptance, wind direction and cooling needs, and so on. Since the 1990s, the bio-meteorological investigations have also embraced social dimensions such as climate appreciation, visitors' demography, 
and activities undertaken. Various tourism comfort assessments and resort qualification benchmarks have been constructed to link climate characteristics to social appreciation. Present studies also include human physiology and psychology to try to predict the optimum conditions for leisure.

Meanwhile, hundreds of millions of people spend more of their personal income on immersing themselves in this seaside air than they spend at home on water and energy all together. Further, global demands for this natural resource are growing faster than the demand for water and energy. As international tourism grows into one of the largest international businesses, the climate of the (sub-) tropical coast is becoming a scarce natural resource of global strategic importance.

\section{Towards a coast warm air monopoly}

A climate suitable for a tourist resort is a scarce commodity. Such seaside conditions are only to be found along about $373,000 \mathrm{~km}$ of (sub-) tropical coasts (about $48 \%$ of the world's total coastline based on Wikipedia data). Making a generous estimate that the average seaside resort is one kilometer wide, the seaside area barely covers $0.3 \%$ of global land area. The exploitable area is even smaller because cities and industries cover large parts of the coast, mountainous and marshy coastal areas are less suitable for resort development, and hot winds are uncomfortable for tourists. The area that can be considered as the natural resource reserve covers no more than $130,000 \mathrm{~km}^{2}$ worldwide (a fraction of the global fresh water surface area). Hence, tourists from all over the world have to be conveyed to these small pockets of land on which land-use intensity is similar to that in densely populated countries such as the Netherlands.

Resort developments need large investments. Firstly, the investors that wish to buy the land face skyrocketing prices for suitable locations because of the growing demands for tourist resorts. Secondly, a minimum critical mass for a resort is something like accommodation for 5,000 beds that can host half a million visitors per year, and this is about a 50 million euro investment. This number of visitors, however, is still insufficient to justify facilities such as shopping malls, restaurants, sport facilities, and playgrounds, and a small resort can be difficult to reach.A more viable resort development, for several million 
visitors a year, requires a stream of investments over a few decades that can approach I billion euro. The investments in hospitality, such as hotels and facilities, largely draw on private funds. These resorts also need infrastructure, such as an airport, roads, marinas, beaches, a supply of energy and water, and waste treatment services. This infrastructure is usually provided from public funds. Developing a resort to maturity is a multi-billion euro investment.

A mature resort, such as Macao or Acapulco, generates a few hundred million euro revenues per year. In the 1980s and 1990s, the revenues per tourist in real terms of 1980, which indicate real prices, were increasing on average by about $3 \%$ a year, although there were fluctuations because tourism is sensitive to people's income fluctuations and hence to wider economic factors. This trend has reversed in the last decade. From the mid-1990s, the real revenues were decreasing on average by $2.5 \%$ a year, despite the global income growth of about $2 \%$ a year.Achieving a sufficient return from tourism, therefore, became difficult. The present financial crisis is putting even more pressure on the revenues. Offering lower prices attracts more tourists, but it becomes harder to make a satisfactory profit.

Given the scarcity of suitable resort locations and the high investment costs, coupled with the downward pressure on what one can charge potential tourists, international tourism businesses are seeking to increase the scale of their operations. Tourism services are becoming standardized with the result that accommodation, services, activities, and even the language in many resorts appear increasingly similar in places such as Antalya (Turkey), Benidorm (Spain), Agadir (Morocco), and Phuket (Thailand). The size of resorts is also expanding and tour operators are merging with hospitality businesses, which provoke allegations of price-fixing.Although the resorts still compete worldwide, there can be an evolution toward regional monopolies if revenues stagnate, despite more visitors, due to price competition. Such falling profits provide legitimacy for monopolies, which remove competition and bring monopoly profits. The emergence of monopolies is already apparent in Egypt, Italy, Jamaica, and elsewhere through concessions granted for attractive seaside locations. Those interested in establishing such resorts are willing to pay for the privilege of monopoly profits, and dividing these profits between themselves and local rulers can appear attractive. Such partnerships undermine the checks and balances that secure open societies, paving way to despotic protection of monopolies. 
Employing questionable methods to gain a share in the monopoly profits is not a fiction; several resorts are already a refuge for criminality, such as money laundering in Marbella (Spain) and drug trafficking on Curacao (Netherlands Antilles). The "warm-air society" unintentionally creates political conflicts.

\section{Alternatives}

The emerging political tensions in international tourism could be eased through innovations that strengthen competition, in an analogy to changes seen in the hydraulic and hydrocarbon societies. The prevailing patterns could be adapted albeit at a risk. One option is ecotourism. This could be fostered through attractions and events related to natural and cultural heritage. Some scholars even advocate monopoly profits in eco-tourism because it would generate high rents from natural resources (Anderson, Croné and Stage, 2005). However, the risk of high rents is crime, like poaching.Another option is climate-conditioned wellness centers inland and in temperate climates. The risk of this option is the emergence of an "economic bubble" where the huge investments in resort development cannot be recovered.

More profound innovations are necessary, in particular the innovations that can invoke new patterns in tourism development. There are several options for innovations. One option is to diversify services. An example of this is seen on the Dutch island of Ameland that combines very intensive tourism with natural local qualities through a diversification of services. This has emerged through the joint interests of local small entrepreneurs and environmental groups that all opposed large-scale project development. Some complain that this pattern involves laborious checks and balances in the community, but this can be a route to more sustainable resorts (Krozer and ChristensenRedzepovic 2006). Another innovative pattern is the virtualization of tourist amenities. The communication and information technologies enable one to share tourism experiences without the physical mobility, such as flying above the Hardangervidda National Park in Norway or meeting giant pandas at the Wolong Center in China, while sitting in front of a screen. Perhaps the next step is to combine these technologies with virtual intelligence, 3D imaging, gaming, and climate-conditioning to provide mass tourism at home or in a neighborhood 'Gameland'. Augmented reality provides, apparently, unlimited 
An essay on tourism and natural resources: a cause of political conflicts

virtual tourism experiences. Still another innovation is a service design based on local resources. Services that are perceived as having high quality and giving a unique experience are emerging such as wine tasting in Tuscany (Italy) and whale watching in Hermanos (South Africa). A slower pace of tourism can become a fashion, with cultural and cooking tours becoming attractive. All these adaptation and innovation options can help foster more sustainable international tourism.

\section{Conclusions}

The global economy is evolving toward "warm-air societies" that annually invest tens of billions of euro in tourism resorts, and recoup hundreds of billions in income despite falling tourism prices. Where businesses and local rulers get a dominant stake in the income, the threat is that checks and balances disappear. This brings the risk of resort monopolies, despotic protection of the monopoly profits and fighting for a share of the cake.

There is no simple solution but innovations that change the prevailing patterns toward sustainable tourism could help. Ecotourism could be developed, although this can end up as a burden on natural and cultural qualities. Air-conditioned warm-air resorts inland ease the pressure on seaside locations but this risks an 'economic bubble' if the investments in new resorts cannot be recovered. New tourism patterns can also be enhanced, such as service diversification involving small-scale enterprises, the virtualization of tourist amenities to delink tourism from physical mobility, and improved customization through the design of high-value services. All these innovations can help prevent the monopolies that evolve into despotism and conflict.

\section{LITERATURE}

Andersson, P., S. Croné, and J. Stage (2005). "Potential Monopoly Rents from International Wildlife Tourism: An Example from Uganda's Gorilla Tourism”. Eastern Africa Social Science Research Review, 2 I (I), I- I8. Beirman, D. (2006). "Best Education Network Think TankV Keynote Address: Marketing Tourism Destination from Crisis To Recovery”. Tourism Review International, I0, 7-I6. 
Cho, M. (2007). “A Re-examination of Tourism and Peace:The Case of the Mt. Gumgang Tourism Development on the Korean Peninsula". Tourism Management, 28, 556-569.

D’Amore, L. (1988). "Tourism - The World Peace Industry”. Journal of Travel

Research, 27 (I), 35-40.

Dasgupta, P.S., and G. H. Heal (1979). Economic Theory and Exhaustible Resources.

Cambridge: Cambridge University Press.

De Freitas, C. R. (1985). “Assessment of Human Response Bioclimate Based on Thermal Response”. International Journal on Biometheorology, 29, 97-II9.

DiLorenzo,T.J.(1996).“The Myth of Natural Monopoly”. The Review of Austrian Economics, 9 (2), 43-58.

Friedman, T. L. (2008). De Toekomst Is Groen.Amsterdam: Nieuwe Amsterdamse Uitgevers (original title Hot, Flat and Crowded: Why We Need Green Revolution - and How lt Can Renew America).

Goldstone, P. (200I). Making the World Safe for Tourism. New Haven:Yale Press. Hazbun, W. (2007). "The East as an Exhibit, Thomas Cook \& Sons and the Origin of the International Tourism in Egypt", in P. Scranton, and J. F. Davidson (eds.). The Business of Tourism, Place, Faith and History. Pennsylvania: University of Pennsylvania Press, 24-26.

Kim, S. S., B. Prideaux, and J. Prideaux (2007). "Using Tourism to Promote

Peace on the Korean Peninsula". Annals of Tourism, 34 (2), 29I-309.

Krozer, Y., and E. Christensen-Redzepovic (2006). "Sustainable Innovations at Tourist Destinations”. Tourism Review International, I 0, I I 3- 24.

Mieczkowski, Z. ( 1985$)$. "The Tourism Climatic Index:A Method of Evaluating World Climates for Tourism”. The Canadian Geographer, 29 (3), 220233.

Mill, J.S. (1985). Principles of Political Economy. Books IV andV. Harmondsworth, Middlesex: Penguin Classic [1848].

Moscardo, G. (2008). "Sustainable Tourism Innovation: Challenging Basic Assumptions". Tourism and Hospitality Research, 8, 4-I3.

Moufakkir, O., and I. Kelly (20I0). Tourism, Progress and Peace.Wallingford: CAB. Pizam,A., and Y. Mansfield (1996). Tourism, Crime, and International Security. New York: John Wiley \& Sons.

Przybyl, G. (2000). Natuurgebied. De Tweede Ronde, Lustrum Nummer, 40-44. Rosenberg, N. (1975). "Technological Innovation and Natural Resources: 
An essay on tourism and natural resources: a cause of political conflicts

The Niggardliness of the Nature Reconsidered”, in N. Rosenberg. Perspective on Technology. New York: Cambridge University Press.

Satani, K. (2004). Peace through Tourism, How Can Tourism Lead to Peace. United Kingdom: University of Bradford, dissertation, mimeo.

Smith, A. ( I 986). The Wealth of Nations. Books I-II. Harmondsworth, Middlesex: Penguin Classic [1776].

Tarlow, P. E. (2006). "Best Education Network Think TankV Keynote Address:

Disaster Management: Exploring Ways to Mitigate Disasters Before they Occur". Tourism Review International, 10, 17-25.

Wittfogel, K.A. (1957). Oriental Despotism. New Haven:Yale University Press. WTO (2006). Tourism Market Trends 2006. Madrid:World Tourism Organization. 